\title{
Adipokine profile in patients with anorexia nervosa
}

\author{
Profil adipokin u pacjentek $\mathrm{z}$ anorexia nervosa
Agnieszka Baranowska-Bik', Bogusława Baranowska², Lidia Martyńska3 , Anna Litwiniuk³, Małgorzata Kalisz', Jan Kochanowski², Wojciech Bik ${ }^{3}$

${ }^{1}$ Department of Endocrinology, Centre of Postgraduate Medical Education, Warsaw, Poland

${ }^{2}$ Department of Neurology, Second Faculty of Medicine, Medical University of Warsaw, Warsaw, Poland

${ }^{3}$ Department of Neuroendocrinology, Centre of Postgraduate Medical Education, Warsaw, Poland

\begin{abstract}
Introduction: Anorexia nervosa (AN) is an eating disorder characterised with extremely low weight. Adipokines are adipose tissuederived substances that show a wide spectrum of biological activities. We aimed to assess selected adipokine levels in women with AN before and after nutritional intervention. We also sought to examine whether BMI is the only confounding factor influencing adipokine assessment in AN.

Material and methods: Sixty-five women participated in the study: 20 individuals with AN before any treatment, 18 AN patients after nutritional intervention lasting for at least six months, and 27 women as controls. In all participants blood collection and anthropometric measurements were performed. ELISA was used for evaluation of leptin receptor, adiponectin and its isoforms, and resistin. Leptin was assessed with RIA, and visfatin was measured with EIA assay.

Results: Leptin and free leptin index (FLI) were lowest in treatment-naïve AN women. HMW-adiponectin and visfatin were enhanced in AN. Other adipokine levels showed no significant differences. When two subsets of anorexia nervosa were compared, only leptin, leptin receptor, and FLI were markedly different. When data were adjusted to BMI, leptin and FLI remained significantly different in the pre-treated AN subgroup when compared with the control group.

Conclusions: Our results suggest that leptin is the most important adipokine in AN. It is also important that in our AN population leptin and FLI are the only factors that are influenced not only by the fat content. (Endokrynol Pol 2017; 68 (4): 422-429)
\end{abstract}

Key words: leptin; soluble leptin receptor; free leptin index; adiponectin; resistin; visfatin; anorexia nervosa

\section{Streszczenie}

Wstęp: Anorexia nervosa (AN) jest zaburzeniem odżywania i charakteryzuje się skrajnie niską masą ciała. Adipokiny to substancje wydzielane przez tkankę tłuszczową o szerokim spektrum aktywności biologicznej.Celem pracy była ocena stężeń wybranych adipokin $\mathrm{u}$ kobiet $\mathrm{z}$ anorexia nervosa przed i po interwencji żywieniowej. Badano również czy wskaźnik masy ciała jest jedynym czynnikiem wpływającym na stężenia adipokin w AN.

Materiał i metody: Udział w badaniu wzięło 65 kobiet: 20 pacjentek z AN przed jakąkolwiek terapią, 18 pacjentek z AN po interwencji żywieniowej trwającej co najmniej 6 miesięcy, 27 kobiet z grupy kontrolnej. U wszystkich uczestniczek przeprowadzono pobranie krwi i badania antropometryczne. Metodą ELISA oznaczano receptor leptynowy, adiponektynę i jej frakcje oraz rezystynę. Leptyna była badana metodą RIA a wisfatyna z użyciem techniki EIA.

Wyniki: Stężenie leptyny oraz indeks wolnej leptyny były najniższe u pacjentek z AN przed leczeniem. Frakcja HMW adiponektyny oraz wisfatyna były podwyższone w przebiegu AN. Wartości pozostałych adipokin nie różniły się znacząco pomiędzy grupami. Porównując podgrupy z anorexia nervosa stwierdzono różnice jedynie w stężeniach leptyny i receptora leptynowego oraz indeksie wolnej leptyny. Dodatkowo po wyłączeniu wpływu BMI jedynie wartości leptyny i indeks wolnej leptyny pozostały znamiennie różne pomiędzy pacjentkami z AN przed leczeniem a grupą kontrolną.

Wniosek: Wyniki naszego badania sugerują, że najważniejszą adipokiną w AN jest leptyna. W naszej grupie pacjentek z AN leptyna i indeks wolnej leptyny były jedynymi czynnikami, których zmiany nie są wyłącznie zależne od zmian ilości tkanki tłuszczowej. (Endokrynol Pol 2017; 68 (4): 422-429)

Słowa kluczowe: leptyna; rozpuszczalny receptor leptynowy; indeks wolnej leptyny; adiponektyną; rezystyna; wisfatyna; anorexia nervosa

\section{Introduction}

Adipose tissue was traditionally considered as an energy reservoir; however, since the discovery of leptin it has been recognised as an endocrine organ. The endocrine activity of adipose tissue consists of the ability to produce and secrete biologically active substances termed adipokines, which maintain energy balance and control metabolism.

Leptin, a peptide derived mostly from adipocytes, has receptors in different organs and tissues dispersed throughout the body. Leptin binds to six types of receptor, but the soluble leptin receptor (sOB-R) has been reported to be the main leptin binding protein. Moreover, 
the ratio of serum leptin levels to sOB-R concentration, named free leptin index (FLI), corresponds with leptin action and determines leptin resistance [1, 2]. A wide spectrum of leptin receptor locations suggests pluripotent activity of this adipokine. Indeed, leptin influences metabolic processes, puberty, reproduction, and immunological processes. Specifically, it plays a role in maintaining body energy balance by central regulation of appetite. [2]. Another important adipokine, adiponectin, is a 244-aminoacid peptide predominantly secreted by adipocytes. It circulates in the periphery in three forms that differ between each other in multimerisation and biological activity: low molecular weight trimer (LMW), medium molecular weight hexamer (MMW), high molecular weight multimer (HMW), and total adiponectin. Adiponectin reveals its activity by binding to two types of receptors, AdipoR1 and AdipoR2. It has been indicated that adiponectin possesses insulinsensitising, anti-atherogenic, and anti-inflammatory properties. Many studies revealed a significant negative correlation between adiponectin and body mass index seen in healthy individuals [2].

Resistin secreted by adipocytes and immunocompetent cells influences metabolic activity including insulin action. Resistin has also pro-inflammatory properties [3].

Visfatin produced and secreted by visceral adipose tissue appears to be a multifunctional protein, acting as a hormone, cytokine, and enzyme, which exerts insulinmimetic and adipogenic properties [2].

Changes in nutritional status and fat content may influence hormonal activity of adipose tissue. The majority of research has focused on obesity and its impact on the adipokine profile. Considerably fewer papers consider the adipokine pattern in chronic undernutrition.

Anorexia nervosa (AN) is an eating disorder characterised by self-induced dietary restrictions leading to extremely low weight. A persistent decrease of fat amount results in hormonal disturbances, adipokine deregulation, and metabolic abnormalities. This disease is an important cause of physical and psychosocial morbidity [4]. Two types of anorexia nervosa are recognised: restrictive (AN-R); and binge eating and purging type (AN-BP) [5]. In recent years a growing number of individuals suffering from anorexia nervosa has been observed [6, 7]. However, the incident rate varies between different populations [8]. To date, no genetic mechanisms underlying AN have been established [9] Previous studies examined the interactions between anorexia nervosa and orexigenic and anorexigenic factors, as well as other peptides and hormones in the control of eating behaviour and energy metabolism in severe undernutrition [10-14]. Most papers focused on adipokine evaluation in malnourished AN individuals, without any assessment after long-term refeeding.

Due to the fact that an extremely low fat amount is typical for individuals suffering from $\mathrm{AN}$, we decided to assess selected adipokine levels in AN women in the acute phase of the disease and after refeeding. We also aimed to examine whether BMI reflecting fat content is the only confounding factor of adipokine profile in AN.

\section{Material and methods}

The study group included thirty-eight women with diagnosed anorexia nervosa. All patients had restrictive subtype of AN. Depending on disease stage, individuals were divided into two different subgroups of patients. The first one included twenty women before any treatment, and the second group comprised another eighteen patients after refeeding. The refeeding process lasted for at least six months and maximum of 12 months. All the patients from the refeeding group underwent nutritional intervention only. No treatment with antidepressants, anxiolytic or neuroleptic drugs, or with oestrogen or oestrogen combined with progesterone was conducted during the time of refeeding. Clinical characteristics of the examined groups are presented in Table I.

All the participants with AN were recruited on a voluntary basis from the Endocrine Outpatient Clinic. The diagnosis of anorexia nervosa was based on the DSM IV.

Twenty-seven healthy women with normal BMI served as a control group. All the controls were volunteers. None of the women among the controls had a history of eating disorders.

Exclusion criteria were established, including endocrine diseases other than eating disorders. Smokers, alcohol abused individuals, and those receiving drugs were not included in the study.

Written, informed consent was obtained from all participants. The study was approved by the Bioethical Committee of the Centre of Postgraduate Medical Education, Warsaw, Poland and was in concordance with the Declaration of Helsinki.

All participants were examined on the day of blood collection, and anthropometric parameters were obtained. Height was measured with use of a wall-mounted ruler. Weight was assessed using a digital scale. Then, BMI was calculated according to the formula: weight $(\mathrm{kg})$ divided by height squared $\left(\mathrm{m}^{2}\right)$

Blood samples were collected after at least eight hours of fasting.

The probes containing EDTA and the protease inhibitor aprotinin were used. Blood was centrifuged at $1200 \mathrm{~g}$ for 10 minutes at $4^{\circ} \mathrm{C}$ to separate plasma. Plasma samples were aliquoted and subsequently 
stored at $-70^{\circ} \mathrm{C}$ until peptide determination assay was performed.

Plasma total adiponectin and isoforms of adiponectin (HMW, MMW, and LMW) were measured using commercial ELISA kits (ALPCO Diagnostics, USA). The sensitivity of the assay was $0.50 \mathrm{ng} / \mathrm{mL}$. Inter-assay and intra-assay $\mathrm{CV}$ were less than $5 \%$ and $10 \%$, respectively.

Plasma leptin levels were determined with a commercial RIA kit (Millipore, USA). Sensitivity of the leptin assay was $0.44 \mathrm{ng} / \mathrm{mlL}$ and inter-assay and intra-assay CV were $8.3 \%$ and $6.2 \%$, respectively.

sOB-R was measured using a commercially available ELISA test (BioVendor Laboratory Medicine, Czech Republic). The sensitivity of the leptin receptor assay was $0.4 \mathrm{ng} / \mathrm{ml}$ and inter-assay and intra-assay CV were $9.81 \%$ and $7.23 \%$, respectively.

FLI was calculated as the ratio of plasma leptin to sOB-R x 100.

Plasma visfatin concentration was measured using EIA Kit (Phoenix Pharmaceuticals Inc., USA). Minimum detectable concentration was $2.3 \mathrm{ng} / \mathrm{mL}$, and intraassay and inter-assay CV were less than $10 \%$ and $15 \%$, respectively.

Resistin was measured using an ELISA kit (BioVendor Laboratory Medicine, Czech Republic). The sensitivity of the assay was $0.012 \mathrm{ng} / \mathrm{mL}$, and inter-assay and intra-assay CV were $8.1 \%$ and $6.6 \%$, respectively.

All statistical analyses were performed using Statistica 10 (StatSoft Inc., USA). Data are presented as mean \pm SD. The normality of distribution for all data was tested with Shapiro-Wilk test. Most of the results presented a lack of normal distribution. For evaluation of statistical significance between groups the Kruskall-Wallis rank test was used followed by Mann-Whitney U test. Significance of correlations between two variables was determined by the Spearman rank correlation coefficient. All $p$ values less than 0.05 were accepted as statistically significant. Data were adjusted to BMI.

\section{Results}

Data concerning clinical data and adipokine levels are presented in Table I.

Leptin concentrations in plasma were lowest in women with AN before treatment and significantly differed when compared with those of patients with AN after refeeding $(3.02 \pm 1.34 \mathrm{ng} / \mathrm{mL}$ vs. $7.36 \pm 5.96$ $\mathrm{ng} / \mathrm{mL} ; \mathrm{p}<0.001)$ as well as with those of the controls $(3.02 \pm 1.34 \mathrm{ng} / \mathrm{mL}$ vs. $12.27 \pm 7.92 \mathrm{ng} / \mathrm{mL} ; \mathrm{p}<0.001)$

In this study, we revealed that sOB-R was significantly higher in AN individuals before treatment in comparison to AN patients after nutritional intervention $(30.44 \pm 5.66 \mathrm{ng} / \mathrm{mL}$ vs.21.28 $\pm 6.23 \mathrm{ng} / \mathrm{ml} ; \mathrm{p}<0.05)$.
FLI, similarly to leptin values, was lowest in severely malnourished women, with significant differences seen when compared both to AN individuals after treatment and the control group $(10.29 \pm 5.20$ vs. $41.59 \pm 39.17$; $\mathrm{p}<0.001$ and $10.29 \pm 5.20$ vs. $82.56 \pm 88.92 ; \mathrm{p}<0.001$, respectively).

Total adiponectin and MMW, as well as LMW adiponectin, showed a non-significant tendency to be enhanced in patients with anorexia nervosa. Moreover, we observed a statistically important increase of HMW adiponectin in both subgroups of AN when compared to the controls (pre-treated AN group $3.52 \pm 1.77 \mathrm{ug}$ / $/ \mathrm{mL}$ vs. controls $2.77 \pm 1.2 \mathrm{ng} / \mathrm{mL} ; \mathrm{p}<0.01$ and after treatment AN group $3.15 \pm 1.85 \mathrm{ng} / \mathrm{mL}$ vs. controls $2.77 \pm 1.2 \mathrm{ng} / \mathrm{ml} ; \mathrm{p}<0.01$, respectively).

Obtained values of visfatin were markedly higher in both AN subsets than in the controls (pre-treated AN group $14.36 \pm 4.11 \mathrm{ng} / \mathrm{mL}$ vs. controls 11.86 $\pm 4.6 \mathrm{ng} / \mathrm{mL} ; \mathrm{p}<0.05$ and after treatment AN group $13.55 \pm 3.60 \mathrm{ng} / \mathrm{mL}$ vs. controls $11.86 \pm 4.6 \mathrm{ng} / \mathrm{mL}$; $\mathrm{p}<0.05$, respectively). Furthermore, assessment of resistin did not reveal any significant differences between all investigated groups.

The results after adjustment to BMI are presented in Table I.

When results were adjusted to BMI, we observed that only leptin and FLI were markedly lower in the pre-treated AN subgroup when compared with the control group ( $\mathrm{p}<0.05$ and $\mathrm{p}<0.05$, respectively). Furthermore, values of leptin and FLI were significantly lower in AN before treatment in comparison to those of AN after refeeding ( $p<0.05$ and $p<0.05$, respectively).

The correlations are presented in Table II.

A number of significant correlations were identified in the study. In the whole group of anorexia nervosa, a positive correlation was seen between leptin and BMI $(r=0.65 ; \mathrm{p}<0.001)$ and a negative correlation was observed between leptin and leptin receptor $(\mathrm{r}=-0.34 ; \mathrm{p}<0.05)$. We also revealed that leptin receptor positively correlated with total adiponectin, HMW, and MMW adiponectin ( $\mathrm{r}=0.38, \mathrm{p}<0.05 ; \mathrm{r}=0.34$, $\mathrm{p}<0.05 ; \mathrm{r}=0.47, \mathrm{p}<0.01$, respectively). Moreover, FLI showed a positive correlation with BMI and a negative correlation with MMW adiponectin $(r=0.67$, $\mathrm{p}<0.001 ; \mathrm{r}=-0.35, \mathrm{p}<0.05$, respectively).

\section{Discussion}

The role of adipose tissue depots includes energy storage, endocrine and metabolic activity, as well as regulation of inflammatory action. Adipocytes are able to produce adipokines that act like classical hormones. Disturbed secretion of adipokines results in obesity, insulin resistance, and type 2 diabetes. On the other 
Table I. Clinical data and adipokine levels

Tabela I. Dane kliniczne i stężenia adipokin

\begin{tabular}{|c|c|c|c|c|c|}
\hline & $\begin{array}{l}\text { AN (AN1) } \\
\text { Before treatment } \\
n=20\end{array}$ & $\begin{array}{l}\text { AN (AN2) } \\
\text { After treatment } \\
n=18\end{array}$ & $\begin{array}{l}\text { Control } \\
\text { Group (C) } \\
n=27\end{array}$ & $\mathbf{p}$ & $\begin{array}{l}p \\
\text { adjusted } \\
\text { to BMI }\end{array}$ \\
\hline Age [years] & $23.1 \pm 8.24$ & $24.23 \pm 7.058$ & $25.52 \pm 5.81$ & NS & - \\
\hline $\mathrm{BMI}\left(\mathrm{kg} / \mathrm{m}^{2}\right)$ & $15.62 \pm 1.13$ & $18.57 \pm 1.60$ & $21.61 \pm 2.08$ & $a, b, c<0.001$ & - \\
\hline $\begin{array}{l}\text { Total Adiponectin } \\
{[\mathrm{ug} / \mathrm{mL}]}\end{array}$ & $6.89 \pm 2.62$ & $6.60 \pm 3.17$ & $5.39 \pm 1.91$ & NS & NS \\
\hline $\begin{array}{l}\text { HMW adiponectin } \\
{[\mathrm{ug} / \mathrm{mL}]}\end{array}$ & $3.52 \pm 1.77$ & $3.15 \pm 1.85$ & $2.77 \pm 1.20$ & $a, b<0.01$ & NS \\
\hline $\begin{array}{l}\text { MMW adiponectin } \\
{[\mathrm{ug} / \mathrm{mL}]}\end{array}$ & $2.16 \pm 1.23$ & $1.79 \pm 0.85$ & $1.71 \pm 0.83$ & NS & NS \\
\hline $\begin{array}{l}\text { LMW adiponectin } \\
{[\mathrm{ug} / \mathrm{mL}]}\end{array}$ & $1.22 \pm 0.83$ & $1.66 \pm 1.11$ & $1.41 \pm 0.66$ & NS & NS \\
\hline $\begin{array}{l}\text { Leptin } \\
{[\mathrm{ng} / \mathrm{mL}]}\end{array}$ & $3.02 \pm 1.34$ & $7.36 \pm 5.96$ & $12.27 \pm 7.92$ & $\begin{array}{l}\text { a, c }<0.001 \\
b<0.01\end{array}$ & $a, b, c<0.05$ \\
\hline $\begin{array}{l}\text { Leptin receptor } \\
{[\mathrm{ng} / \mathrm{ml}]}\end{array}$ & $30.44 \pm 5.66$ & $21.28 \pm 6.23$ & $24.55 \pm 10.70$ & $c<0.05$ & NS \\
\hline Free leptin index (FLI) & $10.29 \pm 5.20$ & $41.59 \pm 39.17$ & $82.56 \pm 88.92$ & $\begin{array}{l}\text { a, c }<0.001 \\
b<0.05\end{array}$ & $\begin{array}{l}a, c<0.05 \\
b=0.07\end{array}$ \\
\hline Resistin [ng/mL] & $3.09 \pm 1.16$ & $3.77 \pm 1.73$ & $3.67 \pm 1.10$ & NS & NS \\
\hline Visfatin $[\mathrm{ng} / \mathrm{ml}]$ & $14.36 \pm 4.11$ & $13.55 \pm 3.60$ & $11.86 \pm 4.60$ & $a, b<0.05$ & NS \\
\hline
\end{tabular}

$a-$ AN1 vs. C; $b-$ AN2 vs. C; $c-$ AN1 vs. AN2

Table II. Correlations in the group of patients with anorexia nervosa

Tabela II. Korelacje $w$ grupie pacjentek $z$ anorexia nervosa

\begin{tabular}{llll}
\hline Parameter A & Parameter $\mathbf{B}$ & $\mathbf{~}$ & $\mathbf{p}$ \\
\hline $\mathrm{BMI}$ & Leptin & 0.65 & $<0.001$ \\
\hline $\mathrm{BMI}$ & Leptin receptor & -0.54 & $<0.001$ \\
\hline $\mathrm{BMI}$ & Free leptin index & 0.67 & $<0.001$ \\
\hline Total adiponectin & Leptin receptor & 0.38 & $<0.05$ \\
\hline HMW adiponectin & Leptin receptor & 0.34 & $<0.05$ \\
\hline MMW adiponectin & Leptin receptor & 0.47 & $<0.01$ \\
\hline Leptin & Leptin receptor & -0.34 & $<0.05$ \\
\hline Free leptin index & MMW adiponectin & -0.35 & $<0.05$ \\
\hline
\end{tabular}

hand, metabolic disorders may heighten dysregulation of adipokine secretion. Data concerning excessive fat amount and its correlation with adipokines have been widely discussed in the literature. However, despite a large body of literature suggesting the occurrence of a dysregulation in both central and peripheral modulators of appetite in AN, there are limited but not conclusive findings on the relationship between adipokines and eating disorders. The typical clinical feature of anorexia nervosa is loss of body fat. Although the total adipose tissue amount is decreased, this unquestionable fact does not always correspond with the disturbed adipokine profile that ought to be, at least theoretically, in opposition to the adipokine pattern seen in obese individuals. Presumably, levels of adipokines in AN should also differ in comparison with those of normalweight controls. In fact, our results did not confirm completely the above-mentioned hypothesis.

Leptin is the first discovered adipokine. It acts peripherally as well as in the central nervous system. It links nutritional status and activity of the brain on the hypothalamus level where hunger/satiety regulating sites are located. Moreover, leptin influences many other physiological processes [2]. Its secretion is stimulated by feeding and reduced by fasting as well as by negative energy balance.

In concordance with this general statement, in our group of patients with AN, we found that leptin levels were significantly lower than those found in the controls. In addition, a marked difference in leptin concentration was also observed between two subsets of AN patients with the lowest values demonstrated in untreated individuals. After adjustment to BMI the differences remained significant.

Decreased leptin levels in acute phase of AN were consistently reported by other authors. A correlation between decreased BMI and low levels of leptin were also described in accessible literature [15-19].

Some researchers performed studies on the effect of weight gain in AN on leptin concentration. It was 
found that leptin may increase during fast refeeding, even to supra-physiological levels, in comparison with BMI-matched healthy controls [20, 21]. However, it was suggested that both plasma and cerebrospinal fluid levels of leptin after a long-term body mass recovery restore to similar concentrations as those seen in healthy, normal weight counterparts [22]. Interestingly, a recent study conducted by Baskaran et al. revealed that not only basal leptin levels are altered in AN but also secretory dynamics of leptin were disturbed with mean pulse amplitude, mean pulse mass, and total pulsatile secretion being low in AN [23].

Our present findings of significant differences in leptin levels between AN individuals and the controls, which remained marked after adjustment to BMI, suggest that it is not only the fat amount that has an impact on decreased leptin concentrations observed in the course of anorexia nervosa. Taking into account the fact that leptin during prolonged caloric deprivation may induce neuroendocrine changes, it could be speculated that dysfunctional hypothalamic activity during fasting might result in lowering of leptin concentration.

In our study sOB-R was markedly decreased in the AN subpopulation after treatment when compared with naïve AN individuals and normal-weight controls. Additionally, the highest values of sOB-R were observed in AN women before any treatment. Consequently, we assessed FLI and found that it was markedly decreased in individuals with AN in comparison with the controls, and the lowest values were seen in untreated patients. Similarly to leptin concentrations, these differences remained significant after adjustment to BMI.

Research reports concerning sOB-R and FLI in AN patients are very limited. Data from the study by Monteleone et al. are consistent with our findings. These authors observed in AN patients low concentrations of leptin and increased values of leptin receptor [19]. Our results also corroborate with those of the group of Misra, who reported a markedly reduced plasma leptin concentration coexisting with enhanced concentration of sOB-R and decreased FLI in AN participants in comparison with healthy adolescents [17]. Moreover, the study on a small group of adolescents with AN by Kratzsch et al. revealed that weight gain in patients with AN resulted in a significant increase in leptin concentration, whereas the median sOB-R values decreased [24]. On the other hand, the group of Krizova reported that sOB-R was significantly enhanced in individuals with $\mathrm{AN}$ and remained unaffected by partial refeeding lasting for six weeks [25].

Based on our current findings and results of other authors who studied leptin, sOB, and FLI in $\mathrm{AN}$, we can draw the conclusion that these factors might be affected by pathophysiological conditions accompanying AN not necessarily associated with changes in body fat storage.

It is well established that circulating levels of adiponectin are inversely associated with BMI and intra-abdominal fat content [2]. Our data showed that the total adiponectin concentration was not markedly different between the groups under study. However, there was a non-significant tendency towards higher values of adiponectin in AN women independently of the disease phase when compared to the healthy controls. These results are in agreement with those reported by Nogueira et al. [26] and Amitani et al. [27]. Moreover, in another study conducted by the group of Iwahashi, individuals diagnosed with AN showed a tendency towards higher adiponectin levels than in the control group. These authors observed also a lack of correlation between adiponectin and BMI in these patients [28]. Furthermore, the group of Misra found that adiponectin levels did not differ in AN girls in comparison with healthy controls. There were no changes in adiponectin values even after weight gain. Interestingly, in this population of girls with $\mathrm{AN}$, adiponectin was not associated with BMI or fat content [29]. BosyWestphal et al. reported no change in adiponectin levels after weight restoration [30]. However, other authors published contradictory data. The majority of researchers demonstrated that total adiponectin values were increased in AN individuals when compared with the controls [15, 18, 30-35]. On the contrary, a decrease in adiponectin concentration in severely malnourished AN patients was reported by Tagami et al. [36].

Data concerning correlation between total adiponectin levels and weight are ambiguous. After adjustment for BMI we did not reveal any significant differences in adiponectin concentrations between the groups under study. These findings are in agreement with the results of the study by Misra et al., who failed to find any associated between adiponectin values and BMI in AN girls [29]. Moreover, Iwahashi et al. did not show any correlation between these parameters [28]. On the other hand, some authors found that enhanced adiponectin in AN individuals was related to lower adiposity [15, $16,18,31$ ]. In addition, Amitani et al. reported higher adiponectin concentration during the acute phase of disease in comparison with those of controls. They observed that these results were even enhanced when adiponectin levels were normalised for BMI [27].

In the literature, there are only a few reports on longitudinal changes in adiponectin concentration during refeeding therapy of AN patients. Generally, assessment of total adiponectin showed a bi-phasic pattern with a temporary increase in the levels of this adipokine observed at the beginning of treatment and a gradual decrease thereafter $[18,27,33]$. However, in the current 
study we did not find significant differences between adiponectin levels when comparing AN individuals before and after refeeding.

To our best knowledge, data concerning the pattern of adiponectin isoforms in AN are limited and equivocal. After analysing adiponectin fractions in AN in comparison with the controls, we found that only high molecular weight form was significantly higher in both subsets of AN. However, after adjustment to BMI these differences changed to non-significant. In addition, there were no differences between the two groups of AN. The group of Modan-Moses was the first to report an increased proportion of HMW isoform in the malnourished phase of AN, followed by a decrease after weight gain to levels similar to control participants [33].Terra et al. also observed a marked increase in HMW adiponectin in AN [18]. These authors found as well that HMW adiponectin related negatively with disease duration after adjustment for age. Moreover, contrary to our findings, these researchers revealed that the weight restoration correlated positively with HMW adiponectin [18]. On the other hand, Amitani et al. failed to find any significant differences when comparing levels of all adiponectin forms of AN individuals and the controls [27]. However, these authors reported that the HMW ratio (HMW to total adiponectin) was significantly lower and the percentage of low-molecularweight (LMW) to total adiponectin (\% LMW) was significantly higher in the AN group compared with the control group. Also, they observed that the HMW ratio positively and the LMW ratio negatively correlated with BMI in the entire study population [27].

The underlying pathophysiological mechanisms that may be attributed to the above described discrepancies in the assessment of total adiponectin and its fractions in AN subjects may result from diversified fat distribution in AN. We should be aware that BMI reports neither body composition nor the location of body fat. In fact, it has been reported that in the course of AN adolescent females lose more central body fat, while adult females lose more peripheral fat. Moreover, it has also been established that partial weight restoration leads to greater fat mass deposition in the trunk region than other body regions in adolescent females. Furthermore, after short-term weight restoration, whether partial or complete, despite lean stature, adults show a central adiposity phenotype when compared to healthy agematched controls [37]. A temporary predominance of trunk fat depots in connection with biological activity of visceral adipose tissue may result in disturbed adipokine secretion and activity, and consequently may predispose to insulin resistance, Generally, adiponectin concentration is closely and inversely related to insulin concentration and insulin resistance, and mirrors the whole body insulin sensitivity.
Visfatin is mainly synthesised in abdominal adipose tissue. Although it influences glucose and insulin homeostasis, the exact physiological role of visfatin is still not defined. Results from our recent research indicated that visfatin levels were markedly higher in AN individuals than in controls. The highest concentrations of visfatin were observed in naïve-to-treatment AN women. However, the results were not significantly different from those of a weight-recovered subset of patients. It is worth highlighting that after adjustment to BMI all differences were changed to non-significant. Data from the literature concerning visfatin levels in AN patients are limited and ambiguous. In one study, visfatin levels in the sera of teenage girls with AN were decreased when compared to the results of their healthy counterparts [38]. On the other hand, in another study no differences were observed between visfatin concentration in AN women and in normal-weight controls [39]. In the publication by Seidel et al. unchanged values of visfatin were also reported in AN individuals, both at the malnutrition stage and after gaining weight, when compared to the control group [40].

It is important to note that reported differences in visfatin levels in AN might be a result of the mutual influence of different factors, including age of patients, body fat distribution, and metabolic activity of adipose cells. In fact, adipose tissue redistribution in the course of AN results in relative abdominal obesity with metabolic consequences that may include insulin resistance [37].

Resistin is a cytokine and it is synthesised by immunocompetent cells of fat tissue. Moreover, significant levels of resistin expression in humans were also found in mononuclear leukocytes, macrophages, spleen, and bone marrow cells. Besides, the relative abdominal adiposity observed in AN subjects might be associated with a state of low-grade chronic inflammation that could have an impact on resistin secretion.

In the present study we failed to find any significant differences in levels of resistin between the examined groups. Our findings are in line with the results of other authors. Terra et al. did not show any marked changes in values of resistin when comparing the results of AN individuals and a control group. The authors reported no correlations between concentration of resistin with disease duration and weight restoration [18]. In the study conducted by Nogueira et al. no significant difference in serum resistin values was seen in the whole AN group when compared with healthy control women [26]. Housova et al. did not reveal any differences in resistin concentration when comparing malnourished individuals with restrictive and the binge/purge subtype of AN with the controls [31]. On the contrary, the group of Dostalova reported that plasma resistin levels were significantly decreased in AN patients with restrictive 
subtype of disease when compared to normal-weight controls [16, 41]. Notably, plasma resistin levels showed no significant correlation to the percentage of body fat and BMI [41]. Decreased levels of resistin in comparison to the controls were also observed in the study by Krizova et al. [32]. Dostalova et al. suggested that the observed low resistin levels in the course of AN were probably related to impaired mononuclear-macrophage number and/or function [16].

Our team presume that resistin secretion in AN might depend on the balance between pro-inflammatory factors and anti-inflammatory activity of the hypothalamic-pituitary-adrenal axis (HPA). In detail, on one hand, the state of low-grade chronic inflammation induces production of cytokines, and on the other hand, central activation of the HPA axis in AN has been widely reported in the literature. The group of Schorr reported that cortisol measures demonstrated a U-shaped relationship with BMI. Furthermore, mean cortisol levels were higher in AN than in obese individuals [42]. Thus, a lack of balance between pro- and anti-inflammatory factors in individuals with AN may affect, among others, adipokine secretion.

We are aware that our study does have several limitations. A major limitation is the number of patients involved in the research protocol. However, we intended to have, as far as it was possible, a homogenic group of AN patients, to avoid confounding factors that could have a negative impact on the results. The second limitation is that only one outpatient unit was included for patient data collection. Thirdly, we did not assess a fat distribution pattern in our subjects with use of precise methods (e.g. DEXA). Instead, we based it on BMI, which is a universal, accessible, and no-cost parameter. Finally, we did not collected data concerning adipokine changes after short-term weight restoration, as was done by others. Therefore, as data concerning adipokine status in AN before and after refeeding require elaboration, further studies are needed.

\section{Conclusions}

Data from our study and findings of other authors show some discrepancies when considering levels of adipokines in the course of anorexia nervosa. Several factors may contribute to these differences, including the number of study participants, age, BMI and/or fat redistribution, concomitant diseases, and finally diversity of laboratory techniques.

Results from the current study suggest that leptin is the most important adipokine in AN. Notably, it is also important that in our AN study population leptin and FLI are the only factors that are influenced not only by the fat content.

\section{Financial support}

The study was supported by CMKP grant no. 501-1-3122-14 and 501-1-31-22-15.

\section{References}

1. yannakoulia M, Yiannakouris N, Blüher S, et al. Body fat mass and macronutrient intake in relation to circulating soluble leptin receptor, free leptin index, adiponectin, and resistin concentrations in healthy humans. J Clin Endocrinol Metab. 2003; 88(4): 1730-1736, doi: 10.1210/ jc. 2002-021604, indexed in Pubmed: 12679465.

2. Kowalska I, Karczewska-Kupczewska M, Strączkowski M. Adipocytokines, gut hormones and growth factors in anorexia nervosa. Clin Chim Acta. 2011; 412(19-20): 1702-1711, doi: 10.1016/j.cca.2011.06.007, indexed in Pubmed: 21699889.

3. Ziora KT, Oswiecimska JM, Swietochowska E, et al. Assessment of serum levels resistin in girls with anorexia nervosa. Part I. Relationship between resistin and body mass index. Neuro Endocrinol Lett. 2011; 32(5): 691-696, indexed in Pubmed: 22167130.

4. Zipfel S, Giel KE, Bulik CM, et al. Anorexia nervosa: aetiology, assessment, and treatment. Lancet Psychiatry. 2015; 2(12): 1099-1111, doi: 10.1016/S2215-0366(15)00356-9, indexed in Pubmed: 26514083.

5. Peat C, Mitchell JE, Hoek HW, et al. Validity and utility of subtyping anorexia nervosa. Int J Eat Disord. 2009; 42(7): 590-594, doi: 10.1002/ eat.20717, indexed in Pubmed: 19598270.

6. Smink FRE, van Hoeken D, Hoek HW. Epidemiology of eating disorders: incidence, prevalence and mortality rates. Curr Psychiatry Rep. 2012; 14(4): 406-414, doi: 10.1007/s11920-012-0282-y, indexed in Pubmed: 22644309.

7. Pike KM, Dunne PE. The rise of eating disorders in Asia: a review. J Eat Disord. 2015; 3: 33, doi: 10.1186/s40337-015-0070-2, indexed in Pubmed: 26388993.

8. Arcelus J, Witcomb GL, Mitchell A. Prevalence of eating disorders amongst dancers: a systemic review and meta-analysis. Eur Eat Disord Rev. 2014; 22(2): 92-101, doi: 10.1002/erv.2271, indexed in Pubmed: 24277724 .

9. Brandys MK, de Kovel CGF, Kas MJ, et al. Overview of genetic research in anorexia nervosa: The past, the present and the future. Int J Eat Disord. 2015; 48(7): 814-825, doi: 10.1002/eat.22400, indexed in Pubmed: 26171770.

10. Misra M, Klibanski A. Endocrine consequences of anorexia nervosa. The Lancet Diabetes \& Endocrinology. 2014; 2(7): 581-592, doi: 10.1016/ s2213-8587(13)70180-3.

11. Misra M, Klibanski A. Neuroendocrine Consequences of Anorexia Nervosa in Adolescents. Endocr Dev. 2009: 197-214, doi: $10.1159 / 000262540$.

12. Warren MP. Endocrine manifestations of eating disorders. J Clin Endocrinol Metab. 2011; 96(2): 333-343, doi: 10.1210/jc.2009-2304, indexed in Pubmed: 21159848 .

13. Baranowska B, Baranowska-Bik A, Bik W, et al. The role of leptin and orexins in the dysfunction of hypothalamo-pituitary-gonadal regulation and in the mechanism of hyperactivity in patients with anorexia nervosa. Neuro Endocrinol Lett. 2008; 29(1): 37-40, indexed in Pubmed: 18283238.

14. Baranowska B, Wolinska-Witort E, Wasilewska-Dziubinska E, et al. The role of neuropeptides in the disturbed control of appetite and hormone secretion in eating disorders. Neuro Endocrinol Lett. 2003; 24(6): 431-434, indexed in Pubmed: 15073570.

15. Delporte ML, Brichard SM, Hermans MP, et al. Hyperadiponectinaemia in anorexia nervosa. Clin Endocrinol (Oxf). 2003; 58(1): 22-29, indexed in Pubmed: $\underline{12519408}$.

16. Dostálová I, Smitka K, Papezová $\mathrm{H}$, et al. Increased insulin sensitivity in patients with anorexia nervosa: the role of adipocytokines. Physiol Res. 2007; 56(5): 587-594, indexed in Pubmed: 17184143.

17. Misra M, Miller KK, Almazan C, et al. Hormonal and body composition predictors of soluble leptin receptor, leptin, and free leptin index in adolescent girls with anorexia nervosa and controls and relation to insulin sensitivity. J Clin Endocrinol Metab. 2004; 89(7): 3486-3495, doi: 10.1210/jc.2003-032251, indexed in Pubmed: 15240636.

18. Terra $X$, Auguet T, Agüera Z, et al. Adipocytokine levels in women with anorexia nervosa. Relationship with weight restoration and disease duration. Int J Eat Disord. 2013; 46(8): 855-861, doi: 10.1002/eat.22166, indexed in Pubmed: 23881663.

19. Monteleone P, Fabrazzo M, Tortorella A, et al. Opposite modifications in circulating leptin and soluble leptin receptor across the eating disorder spectrum. Mol Psychiatry. 2002; 7(6): 641-646, doi: 10.1038/sj.mp.4001043, indexed in Pubmed: 12140788.

20. Chan JL, Mantzoros CS. Role of leptin in energy-deprivation states: normal human physiology and clinical implications for hypothalamic amenorrhoea and anorexia nervosa. Lancet. 2005; 366(9479): 74-85, doi: 10.1016/S0140-6736(05)66830-4, indexed in Pubmed: 15993236. 
21. Monteleone P,Maj M. Dysfunctions of leptin, ghrelin, BDNF and endocannabinoids in eating disorders: beyond the homeostatic control of food intake. Psychoneuroendocrinology. 2013; 38(3): 312-330, doi: 10.1016/i. psyneuen.2012.10.021, indexed in Pubmed: 23313276

22. Monteleone P, Castaldo E, Maj M. Neuroendocrine dysregulation of food intake in eating disorders. Regul Pept. 2008; 149(1-3): 39-50, doi: 10.1016/j.regpep.2007.10.007, indexed in Pubmed: 18582958.

23. Baskaran C, Eddy KT, Miller KK, et al. Leptin secretory dynamics and associated disordered eating psychopathology across the weight spectrum. Eur J Endocrinol. 2016; 174(4): 503-512, doi: 10.1530/EJE-15-0875, indexed in Pubmed: 26903591.

24. Kratzsch J, Lammert A, Bottner A, et al. Circulating soluble leptin receptor and free leptin index during childhood, puberty, and adolescence. J Clin Endocrinol Metab. 2002; 87(10): 4587-4594, doi: 10.1210/jc.2002020001, indexed in Pubmed: 12364439.

25. Krsek M, Rosická M, Haluzík M, et al. Soluble leptin receptor levels in patients with anorexia nervosa. Endocr Res. 2002; 28(3): 199-205, doi: 10.1081/erc-120015058, indexed in Pubmed: 12489569.

26. Nogueira JP, Maraninchi M, Lorec AM, et al. Specific adipocytokines profiles in patients with hyperactive and/or binge/purge form of anorexi nervosa. Eur J Clin Nutr. 2010; 64(8): 840-844, doi: 10.1038/ejcn.2010.66.

27. Amitani $\mathrm{H}$, Asakawa A, Ogiso K, et al. The role of adiponectin multimers in anorexia nervosa. Nutrition. 2013; 29(1): 203-206, doi: 10.1016/j. nut.2012.07.011, indexed in Pubmed: 23237649.

28. Iwahashi H, Funahashi T, Kurokawa N, et al. Plasma adiponectin level in women with anorexia nervosa. Horm Metab Res. 2003; 35(9): 537-540 doi: 10.1055/s-2003-42655, indexed in Pubmed: 14517770.

29. Misra M, Miller KK, Cord J, et al. Relationships between serum adipokines, insulin levels, and bone density in girls with anorexia nervosa. J Clin Endocrinol Metab. 2007; 92(6): 2046-2052, doi: 10.1210/jc.2006-2855 indexed in Pubmed: 17356044.

30. Bosy-Westphal A, Brabant G, Haas V, et al. Determinants of plasma adiponectin levels in patients with anorexia nervosa examined before and after weight gain. Eur J Nutr. 2005; 44(6): 355-359, doi: 10.1007/ s00394-005-0533-3, indexed in Pubmed: 15793670.

31. Housova J, Anderlova K, Krizová J, et al. Serum adiponectin and resistin concentrations in patients with restrictive and binge/purge form of anorexia nervosa and bulimia nervosa. J Clin Endocrinol Metab. 2005; 90(3): 1366-1370, doi: 10.1210/ic.2004-1364, indexed in Pubmed: $\underline{15598689}$.
32. Krízová J, Dolinková M, Lacinová Z, et al. Adiponectin and resistin gene polymorphisms in patients with anorexia nervosa and obesity and its influence on metabolic phenotype. Physiol Res. 2008; 57(4): 539-546, indexed in Pubmed: 17705672.

33. Modan-Moses D, Stein D, Pariente C, et al. Modulation of adiponectin and leptin during refeeding of female anorexia nervosa patients. J Clin Endocrinol Metab. 2007; 92(5): 1843-1847, doi: 10.1210/jc.2006-1683, indexed in Pubmed: 17327386.

34. Karczewska-Kupczewska M, Straczkowski M, Adamska A, et al. Insulin sensitivity, metabolic flexibility, and serum adiponectin concentration in women with anorexia nervosa. Metabolism. 2010; 59(4): 473-477, doi 10.1016/j.metabol.2009.07.036, indexed in Pubmed: 19846178.

35. Pannacciulli N, Vettor R, Milan G, et al. Anorexia nervosa is characterized by increased adiponectin plasma levels and reduced nonoxidative glucose metabolism. J Clin Endocrinol Metab. 2003; 88(4): 1748-1752, doi: 10.1210/jc.2002-021215, indexed in Pubmed: 12679468.

36. Tagami $\mathrm{T}$, Satoh $\mathrm{N}$, Usui $\mathrm{T}$, et al. Adiponectin in anorexia nervosa and bulimia nervosa. J Clin Endocrinol Metab. 2004; 89(4): 1833-1837, doi: 10.1210/jc.2003-031260, indexed in Pubmed: 15070952

37. Paniagua JA. Nutrition, insulin resistance and dysfunctional adipose tissue determine the different components of metabolic syndrome. World J Diabetes. 2016; 7(19): 483-514, doi: 10.4239/wjd.v7.i19.483, indexed in Pubmed: 27895819.

38. Ziora K, Oświęcimska J, Swiętochowska E, et al Assessment of serum visfatin levels in girls with anorexia nervosa. Clin Endocrinol (Oxf). 2012; 76(4): 514-519, doi: 10.1111/j.1365-2265.2011.04181.x, indexed in Pubmed: 21777266.

39. Dostálová I, Sedlácková D, Papezová H, et al. Serum visfatin levels in patients with anorexia nervosa and bulimia nervosa. Physiol Res. 2009; 58(6): 903-907, indexed in Pubmed: 19093738.

40. Seidel M, King JA, Ritschel F et al Serum visfatin concentration in acutely ill and weight-recovered patients with anorexia nervosa. Psychoneuroendocrinology. 2015; 53: 127-135, doi: 10.1016/j.psyneuen.2014.12.010, indexed in Pubmed: 25617618

41. Dostalova I, Kunesova M, Duskova J, et al. Adipose tissue resistin levels in patients with anorexia nervosa. Nutrition. 2006; 22(10): 977-983, doi: 10.1016/j.nut.2006.06.006, indexed in Pubmed: 16889937.

42. Schorr M, Lawson EA, Dichtel LE et al Cortisol Measures Across the Weight Spectrum. J Clin Endocrinol Metab. 2015; 100(9): 3313-3321, doi: 10.1210/JC.2015-2078, indexed in Pubmed: 26171799. 